\title{
The Artpolitics of May Stevens' work: disrupting the distribution of the sensible
}

Abstract: In this paper I look into the life and art of May Stevens, an American working class woman, feminist and committed political activist. I am particularly interested in how Steven's artwork is inextricably interwoven with her politics, constituting, as I will argue an assemblage of artpolitics. The discussion draws on Jacques Rancière's analyses of the politics of aesthetics and particularly his notion of 'the distribution of the sensible'. What I argue is that although Rancière's approach to the politics of aesthetics illuminates an understanding and appreciation of Stevens' art, his idea about the redistribution of the sensible is problematic. It is here that the notion of artpolitics as an assemblage opens up possibilities for a critical project that goes beyond the limitations of Rancière's proposition.

Key words: aesthetics, artpolitics, distribution of the sensible, narratives, women artists

There's an expression that I've used a lot, a quotation from Butler Yeats, who said that you have to choose between 'perfection of the life, or of the work.' I refuse to do that. I will not choose. (Hills, 2005: 11)

In a series of in-depth conversations with Patricia Hill (2005), American artist May Stevens (1924-) rejects Yates' suggestion above about the incompatibility of life and art and insists on keeping them together. It is this agonistic project of fusing life into art and art into life that I will discuss in this paper, focusing on a working class artist, feminist and politically committed activist, who erupted as an event in my overall project of writing a genealogy of the female self in art. (author). What I will argue is that Steven's life and work constitutes a powerful exemplar for understanding entanglements between aesthetics and politics or what I will further discuss as the artpolitics assemblage of her life and work, drawing on Jacques Rancière's influential work and particularly his notion of 'the distribution of the sensible' (2009). The paper will unfold in three sections: first I sketch Steven's pen portrait as an artist, highlighting some events in her life and work within the context of artpolitics. Then I present, explicate and discuss Rancière's approach to the politics of aesthetics and examine how it can illuminate an understanding and appreciation of Stevens' art; in doing this I also highlight the limitations of Rancière's approach in bringing forward the idea of the assemblage drawing on Foucault's and Deleuze and Guattari's analytics. In the final section I return Steven's work and show how the artpolitics assemblage is operationalised in the context of her work, as a theoretical proposition that goes beyond Ranciere's analyses. 


\section{A portrait of the artist}

The only girl in a family of three children, Stevens was born in Dorchester Massachusetts in 1924 and grew up in Quincy. Her father was a pipefitter and her mother a housewife. Coming from a working-class background, Stevens was the first member of her family to go to college: she studied art at the Massachusetts Art School in Boston (MassArt), determined to overcome gender and class barriers and follow the dream of becoming an artist. After her graduation Stevens lived in Boston for more than a year, working in unfulfilling jobs, caring for her mother and doing nothing about her art, but in 1984 she escaped to New York. Life was not easy in New York either, but Stevens joined the Art Students League, a well-established art school founded by students in 1875, where she met her future husband, Rudolf Baranik, a Lithuanian Jewish immigrant, anti-fascist fighter and politically committed artist.

The first time Rudolf came to my room which consisted of a cot, a chair, a bureau, and a window, he closed the door behind him and saw the subway map on the back of the door. I don't think he said anything. But the next time he came, he brought a map of the world. He took down the subway map and put up a map of the world.

(ibid.: 19)

Not only did Baranik bring a map of the world to the artist's room, he also opened up a window to the world in their life through a GI Bill scholarship that gave them the opportunity to go to Paris for three years, between 1948 and 1951. They both enrolled in at the famous Académie Julian, although they were rather unimpressed by its conservatism and were more drawn to Léger's art school, which Baranik eventually followed. In immersing themselves in the post war Parisian art movements and trends, they had the opportunity to study the new masters, or the 'famous four', as they called them, namely, Picasso, Braque, Matisse and Léger, but also avant-guard, although less famous, artists of the time. It was also in Paris that their first and only son, Steven was born, while both artists were getting actively involved in the post-war Parisian life: 'there was this exciting art-Left life that we fell part of. Although we were foreigners and students, we participated emotionally and got to know a lot of people on the art-Left'. (ibid.: 21) Although an art student in Paris, Stevens exhibited on several occasions, while her work was also accepted in a series of annual exhibitions, including the famous Salon d'Automne, Salon de Mai, Salon des Femmes Peintres and the Salon de Feunes Peintres.

On returning to New York Baranik and Stevens worked hard to survive as young artists, raise their child and develop their art. It was while struggling to make ends meet that Stevens got her teaching qualification and became an art teacher first in secondary education and eventually in the School of Visual Arts, where she taught part-time from 1961 to 1996, while also taking visiting artist positions in other universities as well as adult education courses. As has been the case with many women artists, education provided Stevens with the stability of an income that also supported and sustained her work as an 
artist, within the relations of the art/education assemblage that I have elsewhere discussed at length. (See author)

The return to the New York art scene was not easy for Stevens: while in Paris, she had missed out the developments of the abstract expressionism movement and it took her some time to be able to see with her own eyes: 'Things were not immediately accessible to us because we were used to looking with French eyes [...] At first I thought that Pollock's paintings didn't have any structure, they didn't have any rationale [...] When I began to see his work with my own eyes, I realized this is utterly untrue' (ibid.: 26) But it was not just a different 'aesthetics regime', as I will later explain, that Stevens had to grapple with, but also and even more importantly a new artpolitics assemblage that she was being entangled with, not as 'a foreigner' any more, but as a politically committed artist, organically involved in the social movements of the turbulent $60 \mathrm{~s}$, fighting against racism, imperialism, war and sexism. Indeed it was through these movements that Stevens became of age as an artist, actively participating in the politics of aesthetics of the critical art of the 60s. What I suggest is that Stevens' artwork creates a kind of Möbius strip with her politics: they form a continuum that is not orientable and unfolds as a drift of politics into art and of art into politics, an assemblage of artpolitics, which shatters the division between the two and also goes beyond a hierarchical ordering of them either in the form of 'art for the sake of politics', or of the solipsism of 'art for the sake of art'. In putting forward the notion of artpolitics as an assemblage I make connections between Foucault's (1988) and Deleuze and Guattari's (1983) ideas of creating cartographies of discursive and non-discursive practices, power relations and forces of desire, a proposition that I will further discuss in the second section of this paper.

It is thus in this artpolitics assemblage that I have mapped Stevens' early work, 'Freedom Riders' (1963) and the 'Big Daddy Series' (1967-1976)1, two phase in her work, which expressed her involvement in the civil rights movement and the anti-Vietnam war protests, but they were also autobiographically driven. In her conversation with Hills, Stevens explicitly remembers how she was hurt by the fact that 'my father was always a racist. He spoke against blacks, Jews, Italians, and Catholics, which I heard throughout my childhood. I knew it was wrong, and it infuriated me because I loved my father' (ibid.: 29). But she also remembers how she 'heard Martin Luther King Jr. deliver his "I Have a Dream” speech in August 1963, soon after her 'Freedom Rider Series', an exhibition with a small catalogue whose preface was signed by King himself.

While responding to her contradictory feelings, but also expressing her anti-racist and anti-war agonistic politics, Stevens depicted her father in a series of thematically overlapping paintings: as a paper doll, an executioner, a decorated soldier, a policeman or a butcher, sometimes draped in the American flag, others impersonated as the Holly Trinidad and always surrounded by symbolic figures and objects of nationalism, patriarchy, religiosity and violence. Although Stevens made a series of paintings with Big Daddy as the central figure, she considers Big Daddy Paper Doll ${ }^{2}$ as the key image. We have in this early work the emergence of a set of artistic practices that will recur throughout her work: seriality, repetition, oppositions and juxtapositions, the mingling of the personal and the political, auto/biographical portraiture, as well as an early intersectional approach to gender issues. Most importantly we have art and life forming an assemblage 
of relations of interiority and exteriority and it is within and through their entanglement that objects and subjects are constituted as entities and take up meaning within and beyond the world of art. Here Steven's involvement in the second wave feminist movement was a catalytic event: 'When we returned from Paris, I read Simone de Beauvoir's La Vieillesse [...] I also read The Second Sex [...] I was always a feminist in some sense [...] There were many meetings in New York in which we discussed feminist issues.' (ibid.:35) Stevens' feminist activism, led to two important interventions in the Soho community of New York, where she had moved with Baranik between 1967 and 1968: the establishment of an art school, The Feminist Art Institute, and the publication of the feminist journal Heresies: a Feminist Publication on Art and Politics. 'We believe that what is commonly called art can have a political impact, and that in the making of art and of all cultural artifacts, our identities as women play a distinct role', the editorial of the very first issue stated in setting out the agenda of the new publication. (Heresies, 1977, front page)

The journal was edited by an editorial group, four members of which have been included in Stevens' painting Soho Women Artists ${ }^{3}$ (1978). Following the tradition of the masters' group paintings, but significantly challenging its hierarchical and sexist divisions, Stevens has included herself in this painting as well as a number of active members in the Soho art scene of the 1970s. This painting was part of a project of re-imagining women as historical subjects through an intervention in the high genre of historical paintings, which was initiated by The Artist's studio, after Courbet ${ }^{4}$ (1974) and also included Mysteries and Politics $^{5}$ (1978) and Artemisia ${ }^{6}$ (1979). In creating a series of auto/biographical portraits of women artists, Stevens made a powerful aesthetic intervention in the debates of her times and geographies, particularly addressing the burning question that Linda Nochlin had famously raised in her 1971 influential article: Why have there been no great women artists? What is also interesting in this series is that she created both single and collective portraits, thus highlighting the Arendtian existential uniqueness that goes hand in hand with the necessity of acting in concert. (Arendt, 1998) I will come back to the Arendtian elements of Stevens' work later on in the discussion of the Ordinary/Extraordinary series.

What has to be noted here is that feminist politics notwithstanding, Stevens was from the beginning skeptical of the women's movement essentialist trends and definitely resistant to the idea of a new canon, be it feminist or otherwise. In adopting an intersectional approach, Stevens would highlight the fact that social class and race were part and parcel of women's oppression in ways that were often subtle and indiscernible. In this light, in 1982 she invited the black artist Vivian Browne to join Heresies and together they edited a special issue on race, called Racism is the Issue. It was while working together with a black woman artist that Stevens became aware of the whiteness of the feminist movement she was part of and of the importance of self-criticism, but also of communication and mutual understanding in fighting against racist practices and discourses that had become unrecognizable in the ways women artists amongst others made sense of themselves and the world. But while Racism is the Issue was published in 1982, already in the first issue published in 1977, Stevens' contribution was a two-page spread of a collage of photomontages, Tribute to Rosa Luxemburg (1976) and Two Women (1976) 7 bringing together the revolutionary Rosa Luxemburg with her own mother, Alice Stevens. This early artwork eventually became a component in the Ordinary/Extraordinary Series: 
Ordinary. Extraordinary. A collage of words and images of Rosa Luxemburg, Polish/German revolutionary leader and theoretician, murder victim (18711919), juxtaposed with images and words of Alice Stevens (born 1895) housewife, mother, washer and ironer, inmate of hospitals and nursing homes. A filmic sequence of darks and lights moving through close-up to long-view and back. Oblique. Direct. Fragments of Rosa's thought from intimate notes sent from prison to her comrade and lover, Leo Jogiches, and to her friends; from agitprop published in Die Rote Fächne; and from her serious scientific writings. Images from her girlhood, her middle life, and the final photograph of her murdered head. Alice's words from the memory of and letters to her daughter. An artist's book examining and documenting the mark of a political woman whose life would otherwise be unmarked. Ordinary. Extraordinary. (Witzling, 1994: 79)

I was quite moved when I first read this powerful blurb from May Steven's Artist's Book, which appeared in 1980 in the process of the artist's long preoccupation with Rosa Luxemburg that lasted for over ten years (1977-1991) and again returned as a theme in her work in 2001. Ordinary/Extraordinary is a poetic way of bringing two very different women together: the artist's mother and a celebrated political theorist and activist. However as Stevens has remarked in her conversation with Hills, Ordinary/Extraordinary should not be taken as a dualistic opposition between the two women, configuring her mother Alice Stevens as 'ordinary' and Rosa Luxemburg as 'extraordinary'. Both women were for Stevens simultaneously ordinary and extraordinary, a thought whose philosophical line can be traced back to Hannah Arendt's argument about the uniqueness of the human condition, the importance of 'who' one is, as juxtaposed to the inevitable and politically dangerous reduction of 'what' one is, that has historically fuelled totalitarian classifications and in turn resulted in gross human rights violations. (Arendt, 1998) In this light, narratives are particularly instrumental in revealing the 'who' and what the artist's book in the Ordinary/Extraordinary series creates, is an assemblage of visual and textual narratives revealing the unrepeatable uniqueness of human beings:

The text in the book consisted of extracts from Rosa Luxemburg's letters and a few lines from her political writings, and the text for Alice was also lines from letters she wrote and postcards she wrote to me, plus a tissue of narrative that was necessary because I didn't have rich written material from my mother. (Hills, 2005:43)

Epistolary narratives and the force of human communication through writing thus become important compositional elements of the Ordinary/Extraordinary series and have triggered the very ambiguity of the Ordinary/Extraordinary distinction that Stevens was playing with in the artist's book and the subsequent art series: Rosa Luxemburg and Alice Stevens as both ordinary and extraordinary women, exposing themselves through their epistolary fragments as unique and unrepeatable, but also vulnerable, relational and dependent on significant others. Although written 'to the moment', as all letters are, in crystallising the moment and spirit of its creation, the letter intervenes in our perception of linear time and finite life and shows that the force of human life, if rendered into a story, transcends the limitations of the life-span and enters the discourse of history, which 
'ultimately becomes 'the storybook of mankind with many actors and speakers and yet without any tangible author' (Arendt, 1998: 184). Not only do individual human lives enter the discourse of history, Arendt argues, but actually their life stories are creating conditions of possibility for history itself: 'That every individual life between birth and death can eventually be told as a story with beginning and end is the prepolitical and prehistorical condition of history, the great story without beginning and end. (ibid.)

Stevens was particularly preoccupied with this idea of the unfinished story, forcefully and dramatically encapsulated in the famous ending line from Luxemburg's (1919) last known piece of writing, Order Prevails in Berlin, I was, I am, I shall be!' has become for Stevens the phrase that dominates Voices (1983) ${ }^{8}$ - her painting of Luxemburg's funeral - thus transforming her death from an end to an event creating possibilities for new beginnings. Steven's portrayal of Luxemburg's death as an unfinished story, foregrounds three interrelated themes in her approach to life and art: the incessant cycle of life and death, the importance of history painting and the salience of new beginnings, that is also fundamental in Arendt's philosophy: 'the fact that man is capable of action means that the unexpected can be expected from him, that [he] is able to perform what is infinitely improbable.' (1998: 178) A different conceptualization of time runs through these three themes highlighted above. As Stevens has noted:

One of the things that interests me a great deal is simply the idea of time - the approaches to time and the uses of time. You spoke about my showing Alice, my mother and Rosa Luxemburg at different periods in their lives, and I think one of the most interesting things that I've tried to work with is crossing time- by using women of different times and showing their commonalities. (Hills, 2005:40)

In doing this, Stevens creates 'visual biographies' and in presenting different women of different times', it is not just 'significant' events that her artwork captures and recasts. Luxemburg's figure, her political writings, her well-known portraits and her eloquent letters, are repetitively connected to and juxtaposed with Alice Steven's postcards, family photographs, reflections of her daughter and reminiscences of conversations with her, but mostly with her silences: 'Sometimes she held me, rocked me. But she had no words to give. What she wanted to say became too big to be sayable' (Witzling, 1994: 80) In this light, the Ordinary/Extraordinary series creates a very specific version of the grand genre of History Painting, to which of course women artists have had limited access. Lisa Tickner has suggested that 'it is possible to argue for Ordinary/Extraordinary as a kind of history painting transposed to the modern vernacular' (1984, np), while Stevens has included Ordinary/Extraordinary 'in my 'history paintings' [wherein] official versions of history are deconstructed in favour of hearing silenced voices and unrecorded lives.' (Hills, 2005: 38)

After Baranik's death n 1998, soon after their move to Santa Fe, Stevens' life and art took a new turn, both conceptually, as well as in terms of form and subject matter: 'My new paintings tell the story of Rudolf, our life, and our love together. It's not a visible story but one transformed into scene of water with light on it.'(ibid.: 60) In this late phase of her work, which has become 'a little more abstract, a little more universalized, less specific' (ibid), Stevens is mostly preoccupied with fluidity and change, having immersed herself in the politics of the earth that demand new ways of seeing, feeling, understanding and 
acting. The water remembers ${ }^{9}$ was an exhibition held in 2005 at the Minneapolis Institute of Art, showing a rich collection of paintings and works on paper reflecting, both literally and metaphorically Stevens' entanglement in the fluid materiality of the world and the frailty of cosmos. Although more abstract than her previous work, this new cycle in her art again includes words and stories in fragments: 'When I use words in my paintings, they describe some of the ideas and emotions that go to make that painting' (ibid.: 63). What is at the heart of the artist's work is not so much the opposition of life and death, but rather the notion of passage from life to art and from art to politics in an incessant cycle of creating and bringing forward something new, an idea that I will further discuss in the second section of the paper.

\section{The politics of aesthetics: Disrupting the distribution of the sensible}

In highlighting some events in Stevens' artpolitics I have traced a set of artistic practices that clearly mingle and overlap throughout her work. Such artistic practices include aesthetic interventions, but they should not be conflated with them. In marking a distinction between aesthetic and artistic practices in Stevens' work, I draw on Rancière's (2004) analyses of the 'politics of aesthetics' that I now want to discuss. 'Aesthetic practices are forms of visibility that disclose artistic practices', Rancière notes (2004:13), while artistic practices 'are ways of doing and making that intervene in the general distribution of ways of doing and making as well as in the relationships they maintain to modes of being and forms of visibility.' (13) What derives from this succinct, albeit rather dualistic, definition and configuration is that artistic practices are much broader than aesthetic practices, but they are also inextricably interwoven with life, 'ways of doing and making' in Rancière's words. What is also important to highlight here is the notion of 'the distribution', which is central in Rancière's conceptual vocabulary.

Unlike common perceptions, art is not an abstract universal for Rancière but rather a discursive regime, historically, socially, culturally and politically specific. In his work, Rancière has identified three such regimes, which although overlapping they have specific rules of classification and taxonomy underpinning what is recognized and understood as art: the ethical regime, the representational regime and the aesthetics regime. Within the discursive limitations of the ethical regime, art is linked to the notion of originality and truth as exemplary theorized and discussed in Plato. Although derived from and related to the Platonic ideal, the representational regime has historically imposed strict taxonomy rules and classificatory principles encompassed in what Rancière has famously theorized as 'the distribution of the sensible', le partage du sensible:

I call the distribution of the sensible the system of self-evident facts of sense perception that simultaneously discloses the existence of something in common and the determinations that define the respective parts and positions within it. The distribution of the sensible reveals who can have a share in what is common to the community based on what they do and on the time and space in which this activity is performed... it defines what is visible or not in a common space, endowed with a common language, etc. There is thus an 'aesthetics' at the core of politics that has 
nothing to do with Benjamin's discussion of the 'aestheticization of politics' specific to the 'age of the masses'... It is a delimitation of spaces and times, of the visible and the invisible, of speech and noise, that simultaneously determines the place and the stakes of politics as a form of experience. Politics revolves around what is seen and what can be said about it, around who has the ability to see and the talent to speak, around the properties of spaces and the possibilities of time. (Rancière, 2004: $12-13)$

The 'distribution of the sensible' is therefore a system where inclusion and exclusion work hand by hand in defining the grounds, subjects and implicit laws of certain communities of practice and thought. It has to be noted here that the 'sensible' should not be understood as something that makes sense, but as something that can be perceived by the senses, 'what is visible and audible as well as what can be said, thought, made or done' (Rancière, 2004:85). In light of the above, aesthetics is not a discipline for Rancière, but rather a discursive regime within which art takes up meaning, recognition and signification. Moreover, it is only in the aesthetic regime according to Rancière that art is not conceptualised in terms of hierarchies, divisible spaces and times, but as an open plane of playful appearances, always fusing into ways of doing and modes of being, life and art being inextricably interwoven. But this fusion of life and art opens up a battlefield of forces and there is always a tension between art as autonomously standing and art as/in life. In this context, Rancière has further delimited two interrelated planes in the politics of aesthetics: 'the politics of the becoming life of art' (Berrebi, 2006: 2), where diffusion is at work and 'the resistant form' (ibid.), whereby art resists its entanglement into other forms of life and it is from this separation that the politics of the aesthetic experience emerges. It is in the interface of these two politics of aesthetics that Rancière has charted the different trends of the critical art movement of the 60s, which is actually the plane of consistency wherein Stevens' art is situated in my analysis. But although situated in the art/life interface, Stevens has resisted to be on either side of the art/life bipole that Rancière's discussion has identified and criticised: as already noted above, Stevens has explicitly denied to choose between perfection in life and/or perfection in art: 'I have always said I will not let the art dominate my life [...] On the other hand I have always said that the art is the most important thing in my life.' (Hills, 2005: 11) It is this immanent difficulty of understanding the complex web of human relations and actions in terms of dualisms and oppositions that underpins Stevens' resistance to situate herself on either side. In this context, her artistic practices work as what I want to call, anti-rythms in the distribution of the sensible.

In introducing the notion of anti-rhythms in the distribution of the sensible, what I want to argue is that I am deeply skeptical of a correlated notion in Rancière's analyses, the possibility of 'the redistribution of the sensible', his firm conviction that the politics of aesthetics should be about the democratic project of redistribution: 'Democracy, in fact, cannot be merely defined as a political system, one among many, characterized simply by another division of power. It is more profoundly defined as a certain sharing of the perceptible, a certain redistribution of its sites.' (Rancière, 2004:104) Although I am in agreement with the democratic project of redistribution I cannot see how any redistribution will not necessarily involve a new system of the distribution of the sensible. As Ross Birrel has aptly noted, although Rancière's notion of the 'distribution of the 
sensible' is largely influenced by Foucault's and Deleuze's thought, the idea of the possibility of redistribution marks the point where they part company.' (2006: 3)

Differences in the conceptualisation of domination and resistance notwithstanding, I still think the notion of the redistribution as a 'cut' in becoming, opens up an alternative way of conceptualising resistance and it is at this point that I come back to my initial argument about introducing 'anti-rhythms' in the distribution of the sensible rather than arguing about the possibility of a redistribution. In making this proposition I will draw on the notion of the dispositif in Foucault's (1980) analyses as well as Deleuze's and Guattari's (1983) reconfiguration of it as a machinic assemblage, two related notions that as already noted above have been influential in Rancière's theorisation of 'the distribution of the sensible'.

The dispositif, or 'apparatus' as it has been unsuccessfully translated, was first used by Foucault in Discipline and Punish, but was further elaborated in the History of Sexuality. As a Foucauldian concept then, the dispositif is a system of relations that can be established between heterogeneous elements, discursive and non-discursive practices, 'the said as well as the unsaid.' (Foucault, 1980: 194) A dispositif can include 'discourses, institutions, architectural arrangements, regulations, laws, administrative measures, scientific statements, philosophic propositions, morality, philanthropy, etc.' (ibid.) Being inscribed in a play of power the dispositif also relates to certain types of knowledge, which derive from it, but also condition it. It goes without saying that aesthetic ideas, practices and norms are therefore included in Foucault's configuration as explicated above.

Deleuze has underlined two important consequences arising from a philosophy of dispositifs: the rejection of universals, and a drive away from the Eternal and towards the new. As he has written: 'The new is the current. The current is not what we are but rather what we are in the process of becoming - that is the Other, our becoming other.' (Deleuze, 1992: 163-4) He therefore concludes that in each dispositif it is necessary to distinguish the historical part, what we are (what we are already no longer) and the current part, what we are in the process of becoming. Deleuze has further described the dispositif as 'a tangle, a multilinear ensemble' (ibid.: 159), [36] composed of lines and zones that are difficult to determine and localize. These lines are usually deployed in unforeseen directions, while it is amidst crises that new lines are created, and new directions open. (ibid.: 160) As Deleuze sees it, in each dispositif, the analysis has 'to untangle the lines of the recent past and those of the near future: 'that which belongs to the archive and that which belongs to the present.' (ibid.: 164) In the practice of untangling, there are lines of light, lines of force and lines of subjectification emerging from each dispositif. (ibid.: 160) According to the Deleuzian configuration, the lines of light form variable shapes inseparable from the dispositif itself, while each dispositif has its own system of managing light lines and producing light effects, 'distributing the visible and the invisible, giving birth to objects which are dependent on it for their existence and causing them to disappear.' (ibid.: 162) As Deleuze notes, any dispositif 'can be defined from the point of view of the visible and from the point of view of that which can be enunciated.' (ibid) It is particularly Deleuze's commentary on the distribution of the visible and the invisible within the dispositif, I argue, that has been particularly influential for Rancière's concept of 'the distribution of the sensible.' 
But although the dispositif is a critical area where connections between Foucault and Deleuze and Guattari's modes of thought can be made, Deleuze and Guattari have not actually used this notion. One of the key concepts that permeates Deleuze and Guattari's work, running in parallel with the notion of the dispositif, is that of the machine. Unlike closed organisms and fixed identities, machines are assemblages without any organising centre, who can only function as they connect with other machines in a constant process of becoming: 'a machine may be defined as a system of interruptions or breaks [...]Every machine, in the first place, is related to a continual material flow (hylè) that it cuts into.' (Deleuze and Guattari, 1983: 36) The machine has no ground or foundation: 'it is nothing more than the connections and productions it makes; it is what it does; it therefore has no home; it is a constant process of deterritorialization, or becoming other than itself' (Colebrook, 2002: 56) Colebrook explains that 'there is no aspect of life that is not machinic; all life only works and is in so far as it connects with some other machine; [...] so life is a proliferation of machinic connections.' (ibid.) The concept of the machine allows for the possibility of open configurations, continuous connections and intense relations, incessantly transforming life: 'everywhere there are breaks-flows out of which desire wells up, thereby constituting its productivity and continually grafting the process of production onto the product.' (Deleuze and Guattari, 1983: 37)

Given their polyvalent form as assemblages of heterogeneous elements and as sites for the interplay of intense forces, the dispositif and the machinic assemblage create a plane where Foucault's and Deleuze and Guattari's analytics can make connections. (see author) In thus following lines of their thought, what I suggest is that art can be seen as a plane for multiplicities to make connections, as a contested site for power relations and flows of desire to be enacted, in short as both a dispositif and a machinic assemblage, on the grounds of which unknown landscapes emerge, while artistic and aesthetic practices erupt and evolve along moving lines intervening in the distribution of the sensible, disrupting the order of visibility and invisibility, creating ruptures and interstices in what can be seen, heard, understood or appreciated.

\section{Charting anti-rhythms in the distribution of the sensible}

In the previous two sections of this paper I have looked into May Stevens' artistic practices, arguing that they have intervened in the aesthetics of the distribution of the sensible; in this light they have sided with what Rancière has identified as the crucial link between "the "aesthetic" avant-garde and the "political" avant-garde: the invention of sensible forms and material structures for a life to come', a kind of 'aesthetic anticipation of the future'. (Rancière, 2004: 29-30) Art as critique is therefore extended to politics, art and politics becoming constitutive of each other, an assemblage of artpolitics as I have argued. What I therefore want to do in this section is to revisit Stevens' artistic practices and show how they both illuminate and challenge Rancière's analytics of the politics of aesthetics. It goes without saying that Stevens' artistic practices are entangled and interwoven throughout her work and it is impossible to be separated or bounded. In clustering them within groups, I am aware that this is a heuristic and conceptual division 
that simply facilitates the discussion and argument of this paper, opening up a dialogical scene with Rancière's analytics.

a. Creating assemblages of visual images, stories and words:

'I love story, I love narrative, I use it in my work. I tell stories. The stories are anecdotes about events. And they are selected because they mean something to me. I choose them because I see meaning in them.' (Hills, 2005: 11) As I have already discussed in the first section, narratives are not only crucial in understanding the conceptual framework of Stevens' work but are also forcefully and vividly present in the subject matter of her work through a variety of artistic compositions and within different media. By mingling and juxtaposing texts and images, the artist creates a disjunction between what can be read and what can be seen. Luxemburg's letters to her lover Jogiches for example, in the Ordinary/Extraordinary series, disrupt the opposition between the personal and the political, which was at the fore front of second wave feminism, the social movement par excellence that Smith emerged from as an engaged artist in the tradition of the critical art of the 60s. In their critical overview of twentieth-century women artists' self-representation, Sidonie Smith and Julia Watson have delineated four primary ways in which artists may texture the interface to mobilize visual and textual regimes, juxtaposing images and words relationally, contextually, spatially, and temporally. (2002: 21). Although not restricted into self-representation, Stevens' work displays compositional elements and aesthetic practices that respond to all four ways that Smith and Watson have identified.

\section{b. Opening up visual archives of counter-memory}

In Stevens' work, both epistolary texts as well as photographic images, collages and photomontages, function as signs that surprise and wound the viewer. Rosa Luxemburg's blank face, as the only woman in the collective photographic painting of the Second International ${ }^{10}$ is I argue an exemplar of what Roland Barthes has theorized as the punctum/studium relation ${ }^{11}$ : not only does it visualize the harsh gender relations of the socialist European movements at the turn of the twentieth century, but it also acts as a Peircian index ${ }^{12}$, taking the viewer out and beyond the picture to Luxemburg's murder under the eyes of her socialist comrades in 1919. Stevens' portraits/images are thus constituted as a Barthian 'closed field of forces' (2000:13), a battlefield of power relations at play; they also enact Susan Sontag's suggestion that photographs are not so much an instrument of memory, but an invention of the past or a replacement of it. (1979: 165) Stevens actualizes this reinvention of the past by transforming the subject matter of the photographs into paintings. But what does it mean to use photographs as tools for reinventing the past? Drawing analogies between Balzac's literary art in magnifying details ant the photographic operation of enlargement, Sontag has highlighted what I would call the art of the detail, the artistic practice through which 'the spirit of an entire milieu could be disclosed by a single material detail ... the whole of life $[\ldots]$ summed up in a momentary appearance.' (1979: 159) It is this aesthetic practice of magnifying the detail of the photograph through painting it that Stevens' artwork realises. Her portrait/paintings thus open up archives of counter-memories in the genealogical 
histories of women's turbulent positions in the revolutions of modernity, in the case of Luxemburg. (See, author)

c. Creating visual biographies of lives: encounters, entanglements and juxtapositions

As an artist, Stevens was deeply impressed by 'the lives of others' and her work both emerges from and revolves around auto/biographical representations with a range of specific figures recurring throughout her work: her father Ralph, her mother Alice, her son Steven after his suicide ${ }^{13}$, and her husband Rudolf after his death in her late paintings. But apart from her immediate family, Stevens' artwork revolved around familiar, historical and political figures that were influential in her life. What is particularly interesting in Stevens' life-long engagement with the 'lives of others' is that she never actually painted portraits within the limitations and constraints of portraiture. It was in photographs that she found inspiration for representing her subjects and it was through the art of collage and photomontage that she kept bringing different and often distant lives together: her mother and her father as 'together' but so far away in The Family (1967) and The Living Room (1967) ${ }^{14}$, her father and left-wing activists in Big Daddy and George Fackson (1972) ${ }^{15}$, Luxemburg and her mother in the Ordinary/Extraordinary Series, the group paintings of the Soho women artists, Luxemburg and Jogiches in Rosa and Leo (1982/2001) and Luxemburg and her friends in Rosa and Louise Kautsky (1982/2001)16 There is a strong Arendtian element I argue in Stevens' visual representations of the entanglement of human lives and the complexity of the web of human relations. What is central inStevens' visual representations of lives is what Rancière has identified as the aesthetic idea of 'apart we are together' (2008: 1). What brings human beings together, Rancière argues is 'a certain sensory fabric, I would say a certain distribution of the sensible, which defines their way of being together and politics is about the transformation of the sensory fabric of the "being together".' (ibid.: 4) What I therefore suggest is that Stevens' paintings of entangled lives are artistic practices that invite the viewers to think again about the sensory fabric of togetherness as a precondition for any possibility for action and therefore transformation.

d. Visualising temporality in the form of series of repetitions and small differences

As I have already shown in the first section, Stevens' work unfolds in cycles and series, where a motif, a figure or a theme becomes a centre piece around which the artist works and experiments with different techniques and media, including oil paintings, gouaches on paper, ink drawings, collages, photomontages and artists' books amongst others. It is through this diversity of material and art techniques that the artist is trying to unpack the mystery of the world and of human relations, inviting her viewer to be part of this incessant quest for meaning. Time is important in how ideas, evolve, develop and most importantly change and this is why there are always both repetitions and differences in the series that the artist has been working with:

I start with an idea and I always find there's more to say about it, more ways to look at it. I have this thought or this theme and I work on it. And then when I finish, I 
think, oh, but look, you can see it from this side. You can see it from another angle ... I want to really plumb the depths. I want to get to know my subject, make people, invite people, even force people to get involved. Someone said that I don't talk to my audience, that I expect them to work at it. I expect them to get involved, to participate, and to put it together themselves. I love that. Often I think of my work as cinematic. There is a narrative which goes on and changes and you discover more and more the more you spend time with it...I want my paintings to haunt you so that you carry them with you. They raise questions you want to think about, to ponder. (Hills, 2005: 69)

While Stevens visualizes the passage of time through a cinematic mode of differences and repetitions, she also attempts to freeze time by bringing together significant moments through the technique of the collage and visual juxtapositions. Mysteries and Politics (1978) is an exemplary painting in freezing significant moments in women's history, intertwined with Steven's personal and family history, including Rosa Luxemburg, her mother and her feminist friends.

\section{Political aesthetics reconsidered: the artpolitics assemblage}

In bringing together a cluster of intertwined practices in Stevens' artwork, in this paper I have followed four strategies that Rancière has identified in the aesthetic regime of art: play, encounter, archive and mystery. While the critical art of the 60s, 'unambiguous positions and straightforward denunciation' (Berrebi, 2008: 3), today's political aesthetics embrace ambiguity and playfulness as modes of aesthetic intervention in the distribution of the sensible. In this context of playfulness the artist has also become 'a collector and archivist' (ibid) of practices of everyday life, brought together as artistic practices of intervening in the formation and moulding of subjectivities, 'technologies of the self' in Foucault's (1988) theorization of ethics, aesthetics and politics, that were influential in Ranciere's thought. ${ }^{17}$ As Rancière's third strategy 'encounter', Berrebi notes, enacts 'the idea of relational aesthetics', reinserting links in the broken and hollowed texture of the social fabric. (2008: 3) Here Stevens' historical paintings of the Soho artistic community is a very good example of 'relational aesthetics'. Finally, mystery as the fourth aesthetic strategy is best fleshed out the art of the montage, Godard's cinematic sense of montage being Rancière's point of reference. (ibid) Collages and photomontages are indeed recognizable components of Stevens' artwork bringing together as I have already shown, subjects inhabiting different spaces and times.

In light of the above, while Rancière has identified play, encounter, archive and mystery as contemporary critical strategies in the politics of aesthetics what I have shown through glimpses in Stevens' work is that such practices already existed in some trends of the feminist aesthetics that emerged from the critical art of the $60 \mathrm{~s}$ and it is therefore difficult to keep Rancière's periodization between and within the different regimes of art that his analyses has identified, hence my suggestion of the artpolitics assemblage as a more useful conceptual configuration. Difficulties in marking and maintaining boundaries notwithstanding, Rancière has aptly suggested that what distinguishes the aesthetic regime of art today from the paradigm of the critical art of the $60 \mathrm{~s}$ is the recognition that 
there can be no straightforward connection between political awareness through art and political action. The fact for example that Stevens' art has triggered consciousness and awareness around racism and sexism has not necessarily led to political action against such oppressive regimes of power and domination. What her artistic intervention has achieved however in the realm of politics is to mobilize 'processes of disocciation: the break in a relation between sense and sense- between what is seen and what is thought, what is thought and what is felt.' (Rancière, 2008: 12) Rancière maintains that such processes of dissociation, create conditions of possibility for a democratic redistribution of the sensible, although he has been careful to clarify that 'the aesthetic regime of art is not a matter of romantic nostalgia' (ibid.: 14), a return to aesthetic utopias. As I have shown in the second section I am cautious and much less optimistic about the possibilities of 'redistribution'. What I suggest is that artistic 'cuts', such as Stevens', in regimes of sensibility introduce anti-rhythms in the distribution of the sensible and create interstices, ruptures and lacunae, heterotopic spaces as I have elsewhere argued (2000, 2012), wherein new beginnings and new sensorial modes might emerge; here I am in agreement with Rancière that we need to chart 'new passages toward new forms of political subjectivization' (2008: 14), hence my interest in Stevens artpolitics, that I have presented and discussed in this paper.

\section{References}

Arendt, Hannah, 1998 [1958]. The Human Condition. Chicago: University of Chicago Press.

Barthes, Roland, 2000 [1980]. Camera Lucida. Trans. R. Howard. London: Vintage.

Berrebi, Sophie. 2008. 'Jacques Rancière: Aesthetics is Politics'. In Art and Research, a Fournal of Ideas, Contexts and Methods, 2(1), available on line, www.artandresearch.org.uk/v2n1/pdfs/berrebirev.pdf, (accessed, 9-9-2013)

Birrel, Ross. 2008. Jacques Rancière and The (Re)distribution of the Sensible: Five Lessons in Artistic Research. In Art and Research, a fournal of Ideas, Contexts and Methods, 2(1), available on line:

www.artandresearch.org.uk/v2n1/pdfs/v2n1editorial.pdf, (accessed, 9-9-2013)

Colebrook, Claire. 2002. Gilles Deleuze, London, Routledge.

Deleuze, Gilles. 1992a. Foucault, S. Hand (trans). Minneapolis: University of Minnesota Press.

Deleuze, Gilles. 1992b. 'What is a dispositif?' in Michel Foucault, Philosopher: essays translated from the French and German by Timothy F, Armstrong. London: Harvester Wheatsheaf, 15968.

Deleuze, Gilles and Guattari, Felix. 1983 [1977]. Anti-Oedipus: Capitalism and Schizophrenia. (R. Hurley, M. Seem and H. R. Lane, trans) London: The Athlone Press.

Foucault, Michel. 1980. 'The Confession of the Flesh', a conversation in Gordon, C. (ed.) Power/Knowledge: Selected Interviews and other writings 1972-1977, London: Harvester Wheatsheaf, 194-228. 
Foucault, M. 1988. 'An aesthetics of existence', an interview by Alessandro Fontana, 1984, (A. Sheridan, trans). Lawrence D. Kritzman ed. Politics, Philosophy, Culture: Interviews and Other Writings 1977-1984. London: Routledge, 47-53.

Garber, Elizabeth. 1990. 'Feminist Art Criticism: Issues in Feminist Criticism Written About the Work of May Stevens', Marilyn Zurmuehlen Working Papers in Art Education: Vol. 8: Iss. 1, Article 5. Available at: http://ir.uiowa.edu/mzwp/vol8/iss 1/5 (accessed, 7-09-2013)

Hills, Patricia. 2005. May Stevens. San Francisco: Pomegranate, 2005.

Luxemburg, 1909. 'Order prevails in Berlin'. http://www.marxists.org/archive/luxemburg/1919/01/14.htm (accessed, 7-09-2013)

Nochlin, Linda. 1971. 'Why Have There Been No Great Women Artists?' ARTnews January 197 1: 22-39, 67-71.

Rancière, Jacques. 2004. The Politics of Aesthetics. Trans. G. Rochill. London: Continuum.

Rancière, Jacques. 2008. 'Aesthetic Separation, Aesthetic Community: Scenes from the Aesthetic Regime of Art. In Art and Research, a Journal of Ideas, Contexts and Methods, 2(1), available on line, www.artandresearch.org.uk/v2n1/pdfs/ranciere.pdf, (accessed, 9-92013)

Smith, Sidonie and Watson Julia, eds. 2002. Interfaces: Women, Autobiography, Image, Performance. Hawaii: University of Hawaii Press.

Sontag, Susan. 1979. On Photography. London: Penguin.

Tickner, Lisa. 1984. 'May Stevens' in Ordinary/Extraordinary, A Summation 1977-1984.

Witzling, Mara. R. 1994. Ed. Voicing Today's Visions: writings by contemporary women artists. New York: Universe Publishing.

1 See Hills, 2005, Plates 4, 5-15, pp., 87-94, also : http://womenartists.org/post/27122026814/may-stevens-big-daddy

2 http://www.brooklynmuseum.org/opencollection/objects/101647/Big_Daddy_Paper_Doll

${ }^{3}$ Hills, 2005, Plate22, p.98, also: http://www.nmwa.org/works/soho-women-artists

${ }_{4}^{4}$ ibid.,Plate 1974, p.97, also: http://www.persimmontree.org/v2/fall-2009/paintings/

5 ibid., Plate 23, p. 99, http://www.sfmoma.org/explore/collection/artwork/4976

6 ibid., Plates, 17, 18, p.95, alao: http://www.juxtapost.com/site/permlink/208df660-157c-11e2bd6e-37ce5ded9bc8/post/may_stevens_artemisia_1979/

7 http://heresiesfilmproject.org/wp-content/uploads/2011/09/heresies1.pdf (28-29)

${ }^{8}$ Hills, 2005, Plate 31, p. 104, also: http://ir.uiowa.edu/mzwp/vol8/iss1/5 (16)

9 ibid., Plates 66-86, pp. 131-146, also: http://www.artsmia.org/index.php?section_id=2\&exh_id=1721\&IM=1\&start=1

10 ibid., Plate 39, p. 112, Rosa Luxemburg attends the Second International, 1987, also http://www.persimmontree.org/v2/fall-2009/paintings/ (fig. 11). See also the original picture with the names and short bios of the delegates at:

http://rosaluxemburgblog.wordpress.com/2012/07/03/think-you-know-your-leaders-of-the-secondinternational/

${ }^{11}$ In Barthe's analysis, the studium, a kind of a common sense understanding and taste through which we look at and make sense of photographs, while the punctum marks the 'co-presence of two discontinuous elements, heterogeneous in that they do not belong to the same world' (2000: 23), the face of a woman in the photograph of the socialist international in Luxemburg's case. 
12 According to Peircian semiotics, a sign is either an icon, an index or a symbol; an index draws attention to something outside the representation. For a discussion of Peircian semiotics in relation to women artists, see author.

${ }^{13}$ Steven Baranik was a photographer; after his suicide in 1981 Stevens and her husband created a book of his photographs, Burning Horses, which they published without their names. In 1991, Stevens had an exhibition at the DeCordova Museum and Sculpture Park in Lincoln Massachusetts, in collaboration with the artist Civia Rosenberg. The theme of their artwork was an engagement with the mystery of death from the perspective two women artists, who had experienced the loss of their sons as young men taking their own lives.

${ }^{14}$ Hills, 2005, Plate: 2, 3, pp.85, 86.

15 Ibid., Plate 10, p.90, also at: http://boystown.tumblr.com/post/4487651578/may-stevens-bigdaddy-and-george-jackson-1972

16 Ibid,. Plates, 28, 29, p. 102

${ }^{17}$ For an extended discussion of the relation between Foucault's and Ranciere's approach to the politics of aesthetics, see Rancière $(2004: 13,50)$ and author. 